Accepted refereed manuscript of:

Jones IL, Bunnefeld N, Jump A, Peres CA \& Dent D (2016) Extinction debt on reservoir land-bridge islands, Biological Conservation, 199, pp. 75-83.

DOI : $\underline{10.1016 / j . b i o c o n .2016 .04 .036}$

(C) 2016, Elsevier. Licensed under the Creative Commons AttributionNonCommercial-NoDerivatives 4.0 International

http: //creativecommons.org/licenses/by-nc-nd/4.0/ 
1 TITLE:

\section{Extinction debt on reservoir land-bridge islands}

3 AUTHORS:

4 Isabel L. Jones ${ }^{\mathrm{a}^{*}}$, Nils Bunnefeld ${ }^{\mathrm{a}}$, Alistair S. Jump ${ }^{\mathrm{a}}$, Carlos A. Peres ${ }^{\mathrm{b}}$, Daisy H. Dent ${ }^{\mathrm{a}, \mathrm{c}}$

$5 \quad{ }^{a}$ Biological and Environmental Sciences, University of Stirling, Stirling, FK9 4LA, UK.

6 *Corresponding author. Phone +44 (0)7738 009612, email <i.l.jones@ stir.ac.uk>

$7 \quad$ bchool of Environmental Sciences, University of East Anglia, Norwich, NR4 7TJ, UK.

$8 \quad$ 'Smithsonian Tropical Research Institute, Apartado 0843-03092, Balboa, Panama.

9

10 KEYWORDS:

11 Conservation policy; dams; hydropower; fragmentation; isolation; species richness

12 
ABSTRACT

Large dams cause extensive inundation of habitats, with remaining terrestrial habitat confined to highly fragmented archipelagos of land-bridge islands comprised of former hilltops. Isolation of biological communities on reservoir islands induces local extinctions and degradation of remnant communities. "Good practice" dam development guidelines propose using reservoir islands for species conservation, mitigating some of the detrimental impacts associated with flooding terrestrial habitats. The degree of species retention on islands in the long-term, and hence, whether they are effective for conservation is currently unknown. Here, we quantitatively review species' responses to isolation on reservoir islands. We specifically investigate island species richness in comparison with neighbouring continuous habitat, and relationships between island species richness and island area, isolation time, and distance to mainland and to other islands. Species' responses to isolation on reservoir islands have been investigated in only 15 of the $>58000$ large-dam reservoirs (dam height $>15 \mathrm{~m}$ ) operating globally. Research predominantly originates from wet tropical forest habitats and focuses on mammals, with species richness being the most widely-reported ecological metric. Terrestrial taxa are, overall, negatively impacted by isolation on reservoir islands. Reservoir island species richness declines with isolation time, and although the rate of loss is slower on larger islands, all islands exhibit depauperate species richness $<100$ years after isolation, compared to continuous mainland habitats. Such a pattern of sustained and delayed species loss following large-scale habitat disturbance is indicative of an extinction debt existing for reservoir island species: this pattern is evident across all taxonomic groups and dams studied. Thus, reservoir islands cannot reliably be used for species conservation as part of impact mitigation measures, and should instead be included in area calculations for land impacted by dam creation. Environmental licensing assessments as a precondition for future dam development should explicitly consider the long-term fate of island communities when assessing biodiversity loss vs energy output.

\section{INTRODUCTION}


There are 58402 large dams (dam height $>15 \mathrm{~m}$ ) operating globally, constructed predominantly for irrigation and hydropower generation (ICOLD, 2016). A growing human population is predicted to increase the demand for water by $2-3 \%$ per year, and the demand for energy by $>56 \%$ globally between 2010-2040. Energy demand is estimated to rise by $90 \%$ in increasingly industrialised countries with emerging economies over the same period (EIA, 2013; WCD, 2000). Concurrently, changing climatic and precipitation patterns, including severe droughts, will likely further increase demand for water and reduce hydropower generation from large reservoirs (Oki and Kanae, 2006).

Hydropower is regarded as a renewable "green" energy source, and dams constructed in areas with steep topography and high rainfall produce the most energy per unit area (Finer and Jenkins, 2012). However dams are often constructed in low-lying areas with high conservation value: for example 154 dams operate in the Amazon basin with a further 277 planned (Castello et al., 2013; Lees et al., 2016). The construction of dams directly impacts both terrestrial and freshwater ecosystems through inundation of habitat, compositional changes in biological communities, and the loss of structural and functional connectivity between upper and lower reaches of watersheds (Finer et al., 2008; Lees et al., 2016; Nilsson et al., 2005; Palmeirim et al., 2014; Sá-Oliveira et al., 2015).

Over $50 \%$ of the world's large river systems and $>60 \%$ of the combined habitat area of tropical, subtropical and boreal forests, tropical and subtropical grasslands, savannahs and shrublands have been estimated to be impacted by dams (Nilsson et al., 2005). Inundation of terrestrial habitats, and tropical forests in particular, can result in significant carbon emissions from reservoirs in the form of $\mathrm{CO}_{2}$ and $\mathrm{CH}_{4}$, which can persist for many years after inundation and often over the lifetime of the reservoir (Abril et al., 2005; Demarty \& Bastien, 2011; Fearnside, 2002; Fearnside \& Pueyo, 2012). Direct social impacts arise from the loss of indigenous lands, displacement of communities, and disruption to local economies reliant on fisheries often concurrently affected by heavy metal accumulation (Boudou et al., 2005; Fearnside, 1999). Additionally, increased access to previously undisturbed habitat can elevate levels of hunting and deforestation in areas surrounding reservoirs (Kirby et al., 2006; Peres and Lake, 2003). 
When dams are built, habitat is lost through inundation, with remnants of previously continuous

terrestrial habitat confined to highly fragmented land-bridge island archipelagos comprised of former hilltops. "Good practice” guidelines (International Energy Agency, 2006) for dam developers to mitigate ecological impacts from dam construction, include implementing protected areas covering land-bridge islands and habitat surrounding reservoirs. For example, the REBIO Uatumã (the largest Biological Reserve in Brazil) encompasses approximately half of the Balbina hydroelectric reservoir, including all islands east of the former left bank of the Uatumã river and mainland areas extending away from the eastern edge of the reservoir. Strictly-protected area status has largely deterred smallscale slash-and-burn agriculture and extraction of resources within the REBIO Uatumã, on both islands and within surrounding continuous forest (Benchimol \& Peres, 2015a, 2015b). However, we do not know whether protecting reservoir islands is effective for biodiversity conservation, due to a lack of long-term monitoring. The International Energy Agency highlights the dearth of systematic evaluation of any mitigation, enhancement, and compensation measures currently being recommended to large dam developers (International Energy Agency, 2000; Trussart et al., 2002).

Fragmentation of habitat causes a number of impacts to species, such as population reductions and local extinctions; the strength of fragmentation impacts differ depending on the taxonomic group and life-history traits of species (Bender et al., 1998; Fahrig 2003; Forman, 1995; Turner, 1996). Previous studies of reservoir island archipelagos have shown that island taxa typically experience a novel hyper-disturbance regime, resulting in drastic shifts in species diversity and community composition through species turnover, and altered carrying capacity of the remaining habitat (Benchimol \& Peres, 2015a; Cosson et al., 1999b; Ferreira et al., 2012; Hanski \& Ovaskainen, 2000; Terborgh et al., 2001). Local species extinctions on reservoir islands have been observed for plants (Benchimol \& Peres, 2015a; Yu et al., 2012), invertebrates (Emer et al., 2013; Feer \& Hingrat, 2005), birds (Yu et al., 2012), bats (Cosson et al., 1999a), small-mammals (Gibson et al., 2013; Lambert et al., 2003), and midsized to large-bodied vertebrates (Benchimol \& Peres, 2015b, 2015c). Populations of some species can become hyper-abundant on islands, and invasive species can establish, further impacting 
other taxa (Chauvet \& Forget, 2005; Feeley \& Terborgh, 2006; Gibson et al., 2013; Lopez \& Terborgh, 2007).

Changes in island communities may not occur immediately after inundation; instead, species may be subject to an "extinction debt" whereby a portion of species are initially lost, followed, potentially multiple generations later, by further species extinctions (Halley et al., 2014; Kitzes and Harte, 2015; Kuussaari et al., 2009; Tilman et. al., 1994). Thus, the effects of fragmentation and isolation can persist for years after initial habitat loss, as communities undergo "relaxation" towards a new equilibrium community (Diamond, 1972; Diamond, 2001; Ewers and Didham, 2006; Feeley et al., 2007; Terborgh et al., 1997; Wang et al., 2009). The "relaxation" process is likely mediated by island area, with species losses faster on smaller islands, and a greater time-lag for species loss on larger islands (Diamond, 1972; Gonzalez, 2000). There are a number of empirical methods for calculating extinction debt (Kitzes and Harte, 2015; Wearn et al., 2012), and here we consider a decline in species richness on islands over time, compared to mainland continuous habitat, as evidence of extinction debt. In the absence of extinction debt, we assume that all species extinctions would happen immediately, with no evidence of further degradation of insular biological communities through time (Kitzes and Harte, 2015).

In the long-term it is unknown how reservoir island communities will continue change with increasing isolation time, as the creation of artificial archipelagos from dam construction has only occurred over the past century. Our present knowledge of ecological communities within artificial archipelagos comes from multiple snapshot studies from different countries, dams, habitats and taxa, at different time points since the originally continuous habitat was fragmented. Bringing these snapshots together enables identification of general trends across disparate studies, aiding development of policy-relevant recommendations in terms of the conservation value of reservoir islands.

Here, we quantitatively review peer-reviewed research detailing responses of terrestrial taxa to habitat fragmentation and subsequent isolation on reservoir land-bridge islands. We then analyse species 
richness data from 249 islands and adjacent continuous habitats through time. In particular, we ask:

(1) is there evidence of an extinction debt existing for reservoir island species; i.e. compared to continuous habitat, does island species richness decrease with increasing island isolation time? and (2) how does island size, distance to continuous habitat and distance to other islands relate to patterns of species richness and rates of species loss?

\section{METHODS}

\subsection{Literature summary}

\subsubsection{Dataset collation}

We conducted a literature search using Web of Knowledge and Google Scholar search engines between January 2014 and June 2015 using the key words: hydropower or hydroelectric, reservoir or dam, island or land-bridge, and forest islands or fragments. Only full-text, peer-reviewed articles in English were retained; unpublished or grey literature was not included. Studies researching terrestrial species, guilds, taxonomic groups or communities on reservoir islands, attributing ecological responses observed to reservoir creation were retained. Experimental studies or those not explicitly stating an aspect of reservoir creation as a causal factor for the response observed were excluded. Studies which met the inclusion criteria were entered into a dataset (henceforth referred to as "dataset studies"). Literature cited in the dataset studies was also screened for inclusion, and searches for names of dams in dataset studies were performed. A total of 129 studies were assessed for inclusion in our study, 100 of which met the criteria to be retained.

\subsubsection{Data extraction}

Data such as the number of islands surveyed, island area, taxonomic groups investigated, and time since island isolation were extracted from studies (see Appendix A). Each study was assigned a broad habitat type (wet tropical forest, tropical grassland e.g. cerrado, subtropical forest, Mediterranean forest, boreal forest). Taxa investigated were broadly grouped into mammals, birds, invertebrates, 
herptiles, plants, and fungi. If multiple taxa were included within a study, data were extracted for each group separately due to the potential for different responses. The precise isolation time of islands is seldom reported, thus we estimated island isolation time as the year of dam closure minus the year of field data collection. In six studies field data collection dates were not reported, thus, data collection date was conservatively estimated as two years prior to publication date.

\subsubsection{Assigning study response directions}

For each study the authors' key results and conclusions were used to assign an overall response of the study taxa to isolation on islands (response: positive, negative, variable, or neutral; see Appendix A, column ' $L$ '). For example, a study reporting declining species richness on islands would be assigned an overall negative response. An overall positive response would be assigned if, for example, recorded sightings (e.g. presence/absence data) were higher on islands. Overall variable responses could result from research involving different species within the same taxon, e.g. two species of bat exhibiting divergent responses to isolation. Neutral responses would result if no differences or alterations in taxa on islands compared to mainland sites were reported. If authors did not draw a conclusion as to the response directions observed, we examined the data reported and assigned a response direction accordingly. If multiple response directions for the same taxa were observed over time, the predominant response direction (i.e. over most years) was used as the overall direction.

To account for within-study complexity i.e. inclusion of multiple taxonomic groups and/or ecological metrics, response directions were derived for each taxonomic group and ecological metric investigated (see Appendix B, columns 'M-P'). Ecological metrics included species richness, population density, behaviour (e.g. foraging behaviour), community composition, presence/absence, fitness/recruitment (e.g. breeding output), genetic diversity, and functional diversity.

\subsection{Species richness analysis}


Estimates of species richness were the most widely-reported and accessible data available in the collated studies, and therefore we selected this ecological metric for in-depth analysis.

\subsubsection{Data collection}

Dataset studies presenting species richness data for islands and nearby continuous (control) habitat, as well as island areas and isolation time, were used to assess variation in species richness on reservoir islands compared to control habitat (Table B1). These data also allowed investigation of the relationships between species richness and island area, isolation time, distance to mainland and distance to nearest island. Of the 100 dataset studies, 17 presented species richness data for islands (n = 249; size range <1-1690 ha; isolation time <1-92 years) and control sites $(\mathrm{n}=84)$, and were used for the in-depth analysis of species richness data (Table B1; Appendix B). If data for the distance to mainland or nearest island were not presented, then if possible these data were calculated from satellite imagery using Google Earth Pro (Google, 2015). Geographically, the 17 studies suitable for species richness analysis originated from nine dams, located on three continents in three broad habitat types (wet tropical forest, subtropical forest, and tropical grassland; Table B1).

\subsubsection{Data analysis}

For each study the average species richness for control sites was calculated. The ratio of island species richness to average control species richness $\left(S_{\mathrm{RICH}}\right)$ was then calculated for each site and used for analysis (see Appendix B). If a study contained data over multiple years, and thus, multiple isolation times, then species richness for control sites over the same isolation time period was averaged. If a study had multiple species richness values for the same island size, taxon, and isolation time, species richness values were averaged to avoid pseudo-replication.

To normalise data, all data were logged (natural logarithm) prior to analysis. $S_{\mathrm{RICH}}$ values were modelled using linear mixed effects models (lmer using lme4; Bates et al., 2014), as a function of island isolation time $\left(T_{\text {ISO }}\right)$, island area (AREA), distance to mainland ( $\left.D_{\text {MAIN }}\right)$ and distance to nearest island ( $\left.D_{\text {ISLAND }}\right)$ as fixed effects, with taxonomic group (TAXA), dam identity (DAM; a surrogate for 
location), and study (STUDY; to account for differing survey methods and survey intensity among studies) as random effects (Bunnefeld and Phillimore, 2012; see Appendix B). Interaction terms were included between AREA, $T_{\text {ISO, }} D_{\text {MAIN }}$ and $D_{\text {ISLAND }}$, as well as between TAXA, DAM and STUDY; quadratic terms were also tested for.

Due to missing values for $D_{\text {MAIN }}$ and $D_{\text {ISLAND }}$ we reduced the dataset to only those data rows containing values for all variables being tested $(\mathrm{n}$ islands $=178)$ and used this dataset for linear regression and model selection in R ( $\mathrm{R}$ Core Team, 2015). Models were simplified following stepwise deletion of non-significant terms i.e. those with a t-value $<2$ and models compared using Chi-square tests in ANOVA (Crawley, 2005; Table B2). Following model simplification, the final model did not include variables with missing values, thus, the final model was fitted to the whole dataset ( $\mathrm{n}$ islands $=249$ ). The best linear unbiased predictors (BLUPs) for each dam were extracted using the 'ranef' function within the lme4 R package (Pinheiro and Bates, 2000). Each dam has a different intercept, which can fall above or below that of the overall model: positive BLUPs indicate that the dam has higher than expected levels of species richness estimated from the fixed effects, and those falling below the model average indicate that species richness is lower than expected. A variance components analysis was carried out for the random effects (Crawley, 2005).

\section{RESULTS}

\subsection{Literature summary}

The 100 dataset studies examined here were predominantly from Neotropical forest habitats (Fig. 1; 2a). Mammals were the best-studied taxonomic group (Fig. 2b); responses of terrestrial taxa isolated on reservoir islands were most often expressed in terms of species richness and presence/absence, and rarely with regards to behaviour, genetic or functional diversity (Fig. 2c). An overall negative response of terrestrial taxa to dam creation was reported in $>75 \%$ of studies, and these negative responses were seen across all habitat types, ecological metrics, and taxonomic groups investigated 
(Fig. 2a-c). Overall positive responses were confined to only two of the 100 studies (Fig. 2a), of which one reported increased and more stable population densities of small mammals (Adler, 1996), and the second, increased food resources for a raptor due to prey being 'captive' on isolated islands (Benchimol and Venticinque, 2010). Studies report results for islands isolated from $<1$ to 92 years, with the mean island isolation age of $\sim 33$ years (Fig. 2d).

\subsection{Species richness analysis}

The final model for analysis of $S_{\text {RICH }}$ included $T_{\text {ISO }}$ and AREA as fixed effects, and TAXA, DAM and STUDY as random effects (Table 1); $D_{\text {MAIN }}$ and $D_{\text {ISLAND }}$ had no significant effect on $S_{\text {RICH }}$, and no interaction terms were significant (Table B2). Of the random effects, 36\% of variation was explained by STUDY, 17\% explained by DAM, with $47 \%$ residual variance; TAXA did not explain any variance.

For all taxonomic groups and dams, species richness declined with island isolation time, but this effect was mediated by island size with larger islands retaining more species than smaller islands (Fig. 3). For example, predicted $S_{\mathrm{RICH}}$ on the largest island (1690 ha, within the Balbina hydroelectric dam, Brazilian Amazon) is predicted to be 3.2 at the mean isolation time of islands in the analysis, compared to a predicted $S_{\text {RICH }}$ of 1.2 on the smallest island ( 0.17 ha, Cabra Corral, Argentina). In terms of island isolation time, even the largest island studied (1690 ha) exhibits reduced $S_{\text {RICH }}$ in $<30$ years of isolation, and Barro Colorado Island ( 1500 ha, Gatun Lake, Panama), which has been isolated for the longest period in our study ( $~ 92$ years), similarly shows sustained species richness declines (Fig. 3).

The estimates for the random effect of DAM (BLUPs) show that the majority of dams (66\%) maintain lower than expected levels of species richness i.e. species richness values fall below those predicted by the overall model (Fig. 3; Table B3). Only islands in Gatun Lake, Balbina, and Thousand Island Lake maintain higher species richness than predicted. Using our model we can predict $S_{\text {RICH }}$ values for islands of mean area at a given isolation time, and islands of different areas at the mean isolation time, 
for each reservoir. For example, the $S_{\mathrm{RICH}}$ for mean island size within Gatun Lake reduces from 2.24 at five years of isolation to 1.49 after 90 years of isolation. In contrast, in Lake Kenyir which maintains the lowest expected species richness values, a small island of 5 ha (at mean island isolation time) has a predicted $S_{\text {RICH }}$ value of 1.35 , which is increased to just 2.23 on an island of 1000 ha. There was no evidence that islands located nearer other terrestrial habitat or mainland continuous habitat had reduced levels of species loss.

\section{DISCUSSION}

272

Our study finds that terrestrial taxa isolated on reservoir islands experience significant reductions in species richness in less than a century of isolation. Such sustained local species losses after the initial loss of habitat indicates that reservoir island species are subject to an extinction debt, which is evident across all dams, habitats, and taxa. All islands showed depauperate levels of species richness compared to continuous habitats, with smaller islands maintaining lower species richness than larger islands. Island isolation time and area, but not distance from other terrestrial habitat or the mainland, were the drivers of species richness patterns observed.

More broadly, we show that the majority of taxa are negatively impacted by reservoir creation across a range of other ecological metrics including behaviour and genetic diversity. Our current knowledge of the impacts of reservoir creation is disproportionately focussed on mammals, and originates predominantly from evergreen Neotropical forest habitats. While not all dams create archipelagic landscapes, research within our synthesis covers just 15 of the $>58000$ large dams operating globally, representing a small and potentially biased sample of possible island systems. However, even with such limited data we clearly demonstrate the negative impact of dam creation on island species richness. Furthermore, we highlight the shortfalls in current conservation and impact mitigation strategies for dam development, particularly in terms of long-term biological costs, in addition to the immediate direct loss of lowland habitat during flooding. 
294 Classic island biogeography theory (IBT, MacArthur \& Wilson, 1967) explains variation in island species richness through a balance of species immigration and distance from species source pools. In the artificial archipelagic systems we investigate in our analysis, rather than a process of species accumulation on islands, remnant communities of formerly continuous habitat undergo species loss (“relaxation") until a new equilibrium community is reached (Diamond, 1972; Gonzalez, 2000; Lomolino, 2000).

300

Area was a significant predictor of species richness on islands within our analysis, as expected from the species-area relationship and IBT (Connor \& McCoy, 1979; MacArthur \& Wilson, 1967; Triantis et al., 2012). However distance, both to the mainland and other islands, was not a significant predictor of island species richness: this represents a departure from the IBT, and suggests the reduced importance of metapopulation dynamics (Hanski and Gilpin, 1991; With and King, 2001) and the "rescue effect" (Brown and Kodric-Brown, 1977) for maintaining insular populations in artificial archipelagic systems.

In the case of reservoir islands, remnant terrestrial habitat fragments are surrounded by a highcontrast, inhospitable water matrix, presenting a prohibitive dispersal barrier for certain taxa. Such an extreme dispersal barrier effectively renders all islands as too isolated for any "rescue effect" from wider species source pools to maintain island communities and species richness, and explains the lack of distance effects we find in our analysis (Watson, 2002). The evolutionary history and traits of species resident in continuous habitats make many incapable of dispersing through open habitats, across large distances, or through a high-contrast matrix such as open water (see Fig. 2 in Ewers \& Didham, 2006). For example, the ability of tropical understorey bird species to disperse across a water matrix between islands was tested in Gatun Lake, Panama, where some species were limited to $<100 \mathrm{~m}$ of flight (Moore et al., 2008); species reliant on continuous habitats can be averse to crossing 
even small clearings, such as logging roads, even when the forest canopy is closed (Develey \& Stouffer, 2001; Laurance et al., 2004).

Habitat fragments surrounded by water therefore represent a worse-case scenario in terms of fragmentation effects; aside from the dispersal barrier preventing species migration, islands are subject to extreme edge effects from e.g. increased UV and wind damage, often penetrating deep into islands leading to further degradation of island biota (Benchimol \& Peres, 2015b; Laurance, 2008; Murcia, 1995). Habitat fragments embedded within a more similar and potentially hospitable, but low-quality, terrestrial habitat matrix (e.g. forest fragments within an agricultural landscape) can retain higher levels of species diversity, with reduced local extinction rates (Mendenhall et al., 2011), when compared to reservoir islands of a similar size (Mendenhall et al., 2014).

We find a reduction in species richness on all islands with increasing time since initial habitat loss. Such a pattern of sustained and delayed species loss is indicative of extinction debt (Tilman et al., 1994; Kitzes \& Harte, 2015; Kuussaari et al., 2009). Extinction debts are especially high in areas subject to recent large-scale habitat loss, such as islands created by rapid flooding of terrestrial habitats (Hanski and Ovaskainen, 2002). Our analysis illustrates that reservoir islands are of limited long-term conservation value, due to evidence of an extinction debt: species loss appears most rapid on smaller islands, but even the largest islands studied ( 1690 ha) exhibited lowered species richness in under 30 years of isolation. Ongoing species losses have been reported on another large island in our synthesis: Barro Colorado Island (BCI, $\sim 1500$ ha) has been isolated for 92 years since the formation of the Gatun Lake, Panama. In less than a century of island isolation, and despite strict environmental protection of BCI and surrounding peninsulas, 65 bird species (Robinson, 1999) and 23 butterfly species (Basset et al., 2015) have become locally extinct, alongside long-term degradation of the tree community (Leigh et al., 1993). In the Balbina hydroelectric mega-dam system in Amazonia, Benchimol and Peres (2015b) calculated that a threshold island size of 475 ha was needed to conserve $>80 \%$ of terrestrial and arboreal vertebrates on islands. However, only 25 out of 3546 islands in the Balbina archipelago meet this size criterion. Balbina is protected by the largest biological reserve in 
Brazil, and thus represents a best case scenario for biodiversity conservation within an artificial archipelago system. Species inhabiting other such systems, without protection, will therefore likely suffer not only from direct habitat loss through flooding and potential extinction debt, but additional human-mediated impacts such as deforestation, agriculture, hunting, and fire (Laurance, 2008; Peres, 2001).

The data we use for analysis of species richness on reservoir land-bridge islands originate from 249 islands within 9 of the 15 dams presented in Fig. 1 and allow us to show patterns applicable to all dams and taxonomic groups, although we acknowledge that publication bias towards negative impacts of reservoir creation could influence the response patterns presented. While the data do not allow us to disentangle species richness patterns for individual taxonomic groups, dams and habitat types, we have addressed this shortcoming by using random effects in linear mixed effects models (Bunnefeld and Phillimore, 2012). Similarly we cannot calculate the magnitude of extinction debts for individual taxonomic groups and/or habitat types, and instead highlight evidence that all reservoir islands are subject to an extinction debt, and therefore cannot be relied upon for long-term species conservation.

It is possible that the observed patterns of depauperate island species richness could be shaped by landscape attributes prior to inundation and non-random loss of more species-rich lowland habitat during flooding (Seabloom et al., 2002). Mainland species richness levels may have been elevated through surveying lowland habitats; such a potential sampling effect should be accounted for during survey site selection (e.g. Benchimol and Peres, 2015a). In continuous habitats the greater availability of resources allows more species to inhabit a given area, compared to the same area of isolated habitat (Ewers and Didham, 2006). Thus, sampling islands can inherently give lower species richness values than an equal area of continuous habitat (Crawley \& Harral, 2001; Gonzalez, 2000; Halley et al., 2014; MacArthur \& Wilson, 1963).

\section{Data for island taxa in artificial archipelagos come from snapshots of responses to isolation in $<100$} years of reservoir lifetime, across multiple taxa and habitat types. In addition, no studies monitored 
changes in insular community dynamics over a significant post-isolation time. Consequently, we cannot currently determine if the rates of local species loss are predictable beyond the relatively short time frame analysed here. Nor can we accurately quantify extinction debt to predict the eventual number of species able to persist in the artificial archipelago systems created due to the assumptions that would be required to do so. Further long-term monitoring of reservoir island biota is needed to allow these more detailed assessments to be made, since at present only Gatun Lake, Panama, provides data for a reservoir $>90$ years of age.

\subsection{Conservation implications}

Our study strongly suggests that islands within reservoir systems do not sustain full complements of flora and fauna in the long term; larger islands retain species for longer than smaller islands, but all island communities likely face an extinction debt. Given that degradation of island communities can be predicted to occur in all artificial archipelagic systems created by dam development, we emphasise that reservoir islands cannot be used for species conservation as part of impact mitigation strategies.

The combined area of reservoir islands should be explicitly included in environmental impact assessments, in addition to the area of habitat directly lost through inundation.

Current policy to mitigate the negative impacts of dam creation on terrestrial environments consists of "good practice" guidelines with no statutory legislation requiring specific actions by developers (International Energy Agency, 2006). Environmental legislation is highly variable among countries, and there is no signatory international agreement on how to forecast, prevent or mitigate the effects of large dams. Mitigation measures can take a multitude of forms, ranging from conducting wildlife inventories and environmental impact assessments before reservoir filling, creating new habitats such as wetland zones within the reservoir system, and conservation offsets such as strictly protecting land both within and surrounding reservoirs. There is however no long-term monitoring of such practices to assess whether these mitigation measures are effective (International Energy Agency, 2000). 
In light of the many dams that are planned to meet future water and electricity needs, especially in developing countries, we call for better trade-off calculations (Kareiva, 2012) to be made for future dams, accounting for long-term species loss on islands created by flooding. In addition, enhanced protection of larger islands and surrounding non-fragmented habitats is essential to avoid biological collapse in artificial archipelagic systems. We highlight the potential for additional impacts from long-term degradation of high carbon-storing habitats such as tropical forests, where erosion of island tree communities (Benchimol and Peres, 2015a) could lead to future carbon loss from tropical dams, exacerbating the greenhouse gas emissions already documented from this "green" energy source (Demarty and Bastien, 2011; Fearnside, 2009).

\subsection{Conclusions}

We have shown that there is an overall negative response of terrestrial species and communities to isolation on reservoir land-bridge islands. These trends are seen across a broad spectrum of taxonomic groups and ecological metrics. Species isolated on reservoir islands will likely experience extinction debt, and the rate of local extinctions is driven by island size and island isolation time, independently of distance from potential source populations within the landscape. Our synthesis of current literature allows broad conclusions about the ecological impacts of reservoirs through time, and highlights the need for further research from a greater number of reservoirs over the duration of their lifetime. Building upon the findings that we present here, investigation of the many other direct and indirect ecological impacts of reservoirs, such as loss of river habitats and connectivity, land tenure rights, and the impacts of wider infrastructure development on surrounding habitats, should be a priority for future research.

\section{Acknowledgements}



greatly improved the manuscript.

\section{Role of the funding source}

435

This study was funded by the University of Stirling (UoS). UoS was not involved with the study

design, data collection, analysis or interpretation of data, writing or decision to submit this

manuscript.

\section{REFERENCES}

440

441

442

443

444

Abril, G., Guérin, F., Richard, S., Delmas, R., Galy-Lacaux, C., Gosse, P., Tremblay, A., Varfalvy, L., Dos Santos, M.A., Matvienko, B., 2005. Carbon dioxide and methane emissions and the carbon budget of a 10-year old tropical reservoir (Petit Saut, French Guiana). Global Biogeochem. Cycles 19, GB4007. doi:10.1029/2005GB002457

Adler, G.H., 1996. The Island Syndrome in Isolated Populations of a Tropical Forest Rodent. Oecologica 108, 694-700. doi: 10.1007/BF00329044

Basset, Y., Barrios, H., Segar, S., Srygley, R.B., Aiello, A., Warren, A.D., Delgado, F., Coronado, J., Lezcano, J., Arizala, S., Rivera, M., Perez, F., Bobadilla, R., Lopez, Y., Ramirez, J.A., 2015. The Butterflies of Barro Colorado Island, Panama: Local Extinction since the 1930s. PLoS One 10, e0136623. doi:10.1371/journal.pone.0136623

Bates, D., Maechler, M., Bolker, B., Walker, S., 2014. lme4: Linear mixed-effects models using Eigen and S4. URL: http://cran.r-project.org/package=lme4 [Accessed 21/12/15]

Benchimol, M., Peres, C. A, 2015a. Edge-mediated compositional and functional decay of tree assemblages in Amazonian forest islands after 26 years of isolation. J. Ecol. 103, 408-420. doi:10.1111/1365-2745.12371

Benchimol, M., Peres, C. A, 2015b. Predicting local extinctions of Amazonian vertebrates in forest islands created by a mega dam. Biol. Conserv. 187, 61-72. doi:10.1016/j.biocon.2015.04.005

Benchimol, M., Peres, C.A., 2015c. Widespread Forest Vertebrate Extinctions Induced by a Mega Hydroelectric Dam in Lowland Amazonia. PLoS ONE 10(7): e0129818. doi: 10.1371/journal.pone.0129818

Benchimol, M., Venticinque, E.M., 2010. Harpy Eagle (Harpia harpyja) predation on an Infant brown Capuchin Monkey (Cebus apella) in the Brazilian Amazon. Rev. Bras. Ornitol. 18, 352-354

Bender, D.J., Contreras, T.A., Fahrig, L., 1998. Habitat loss and population decline: a meta-analysis of the patch size effect. Ecology 72(2), 517-533. doi:10.2307/176950 
Boudou, A., Maury-Brachet, R., Coquery, M., Durrieu, G., Cossa, D., 2005. Synergic Effect of Gold Mining and Damming on Mercury Contamination in Fish. Environ. Sci. Technol. 39, 24482454. doi:10.1021/es049149r

Brown, J.H., Kodric-Brown, A., 1977. Turnover Rates in Insular Biogeography: Effect of Immigration on Extinction. Ecology 58, 445-449. doi:10.2307/1935620

Bunnefeld, N., Phillimore, A.B., 2012. Island, archipelago and taxon effects: mixed models as a means of dealing with the imperfect design of nature's experiments. Ecography 35, 15-22. doi: 10.1111/j.1600-0587.2011.07078.x

Castello, L., McGrath, D.G., Hess, L.L., Coe, M.T., Lefebvre, P. A., Petry, P., Macedo, M.N., Renó, V.F., Arantes, C.C., 2013. The vulnerability of Amazon freshwater ecosystems. Conserv. Lett. 6, 217-229. doi:10.1111/conl.12008

Chauvet, S., Forget, P.-M., 2005. Edge effects on post-dispersal seed removal in a fragmented rain forest in French Guiana. J. Trop. Ecol. 21, 113-116. doi:10.1017/S0266467404001944

Connor, E.F., McCoy, E.D., 1979. The Statistics and Biology of the Species-Area Relationship. Am. Nat. 113, 791-833. doi:10.1086/283438

Cosson, J., Pons, J.-M., Masson, D., 1999a. Effects of forest fragmentation on frugivorous and nectarivorous bats in French Guiana. J. Trop. Ecol. 15, 515-534

Cosson, J.F., Ringuet, S., Claessens, O., de Massary, J.C., Daleky, A., Villiers, J.F., Granjon, L., Pons, J.M., 1999b. Ecological changes in recent land-bridge islands in French Guiana, with emphasis on vertebrate communities. Biol. Conserv. 91, 213-222. doi:10.1016/S00063207(99)00091-9

Crawley, M.J., 2005. Statistics: an introduction using R. John Wiley \& Sons Ltd, Chichester

Crawley, M.J., Harral, J.E., 2001. Scale dependence in plant biodiversity. Science 291, 864-868. doi:10.1126/science.291.5505.864

Demarty, M., Bastien, J., 2011. GHG emissions from hydroelectric reservoirs in tropical and equatorial regions - review of 20 years of $\mathrm{CH}_{4}$ emission measurements. Energy Policy 39, 41974206. doi:10.1016/j.enpol.2011.04.033

Develey, P.F., Stouffer, P.C., 2001. Effects of Roads on Movements by Understory Birds in MixedSpecies Flocks in Central Amazonian Brazil. Conserv. Biol. 15, 1416-1422. doi:10.1111/j.15231739.2001.00170.x

Diamond, J.M., 1972. Biogeographic Kinetics: Estimation of Relaxation Times for Avifaunas of Southwest Pacific Islands. Proc. Natl. Acad. Sci. USA 69, 3199-3203. doi:10.1073/pnas.69.11.3199

Diamond, J.M, 2001. Dammed Experiments! Science 294, 1847-1848. doi:10.1126/science.1067012

EIA, 2013. International Energy Outlook 2013. U.S. Energy Information Administration, Office of Energy Analysis, U.S. Department of Energy, Washington, DC 20585 
Emer, C., Venticinque, E.M., Fonseca, C.R., 2013. Effects of dam-induced landscape fragmentation on Amazonian ant-plant mutualistic networks. Conserv. Biol. 27, 763-73. doi:10.1111/cobi.12045

Ewers, R.M., Didham, R.K., 2006. Confounding factors in the detection of species responses to habitat fragmentation. Biol. Rev. 81, 117-42. doi:10.1017/S1464793105006949

Fahrig, L., 2003. Effects of Habitat Fragmentation on Biodiversity. Annu. Rev. Ecol. Syst. 34, 487515. doi:10.1146/132419

Fearnside, P.M., 1999. Social Impacts of Brazil's Tucurui Dam. Environ. Manage. 24, 483-495.doi: $10.1007 / \mathrm{s} 002679900248$

Fearnside, P.M., 2002. Greenhouse Gas Emissions from a Hydroelectric Reservoir (Brazil's Tucurui Dam) and the Energy Policy Implications. Water. Air. Soil Pollut. 133, 69-96. doi: 10.1023/A:1012971715668

Fearnside, P.M., 2009. Hydroelectric Dams in the Brazilian Amazon as Sources of 'Greenhouse' Gases. Environ. Conserv. 22(1), 7-19. doi: 10.1017/S0376892900034020

Fearnside, P.M., Pueyo, S., 2012. Greenhouse-gas emissions from tropical dams. Nat. Clim. Chang. 2, 382-384. doi:10.1038/nclimate1540

Feeley, K.J., Gillespie, T.W., Lebbin, D.J., Walter, H.S., 2007. Species characteristics associated with extinction vulnerability and nestedness rankings of birds in tropical forest fragments. Anim. Conserv. 10, 493-501. doi:10.1111/j.1469-1795.2007.00140.x

Feeley, K.J., Terborgh, J.W., 2006. Habitat Fragmentation and Effects of Herbivore (Howler Monkey) Abundances on Bird Species Richness. Ecology 87, 144-150. doi:10.1890/05-0652

Feer, F., Hingrat, Y., 2005. Effects of Forest Fragmentation on a Dung Beetle Community in French Guiana. Conserv. Biol. 19, 1103-1112. doi:10.1111/j.1523-1739.2005.00087.x

Ferreira, L. V, Neckel-Oliveira, S., Galatti, U., Fáveri, S.B., Parolin, P., 2012. Forest structure of artificial islands in the Tucuruí dam reservoir in northern Brazil: a test core-area model. Acta Amaz. 42, 221-226

Finer, M., Jenkins, C.N., 2012. Proliferation of hydroelectric dams in the Andean Amazon and implications for Andes-Amazon connectivity. PLoS One 7, e35126. doi:10.1371/journal.pone.0035126

Finer, M., Jenkins, C.N., Pimm, S.L., Keane, B., Ross, C., 2008. Oil and gas projects in the Western Amazon: Threats to Wilderness, Biodiversity and Indigenous Peoples. PLoS One 3, e2932. doi:10.1371/journal.pone.0002932

Forman, T.T., 1995. Land mosaics: the ecology of landscapes and regions. Cambridge University Press, Cambridge.

Gibson, L., Lynam, A.J., Bradshaw, C.J.A, He, F., Bickford, D.P., Woodruff, D.S., Bumrungsri, S., Laurance, W.F., 2013. Near-complete extinction of native small mammal fauna 25 years after forest fragmentation. Science 341, 1508-10. doi:10.1126/science.1240495 
Gonzalez, A., 2000. Community relaxation in fragmented landscapes: the relation between species richness, area and age. Ecol. Lett. 3, 441-448. doi:10.1046/j.1461-0248.2000.00171.x

Google, 2015. Google Earth Pro. URL: http://www.google.co.uk/earth/download/gep/agree.html [Accessed 21/12/15]

Halley, J.M., Sgardeli, V., Triantis, K.A., 2014. Extinction debt and the species-area relationship: a neutral perspective. Glob. Ecol. Biogeogr. 23, 113-123. doi:10.1111/geb.12098

Hanski, I., Gilpin, M., 1991. Metapopulation dynamics: brief history and conceptual domain. Biol. J. Linn. Soc. 42, 3-16. doi:10.1111/j.1095-8312.1991.tb00548.x

Hanski, I., Ovaskainen, O., 2000. The metapopulation capacity of a fragmented landscape. Nature 404, 755-758. doi: doi:10.1038/35008063

Hanski, I., Ovaskainen, O., 2002. Extinction Debt at Extinction Threshold. Conserv. Biol. 16, 666673. doi:10.1046/j.1523-1739.2002.00342.x

ICOLD, 2016. International Commission on Large Dams. URL: http://www.icold-cigb.org/ [Accessed 21/03/16]

International Energy Agency, 2000. Hydropower and the Environment: Effectiveness of Mitigation Measures. IEA Technical Report, Annex III - Subtask 6

International Energy Agency, 2006. Annex VIII, Hydropower Good Practices: Environmental Mitigation Measures and Benefits. New Energy Foundation, Japan

Kareiva, P.M., 2012. Dam choices: Analyses for multiple needs. Proc. Natl. Acad. Sci. 109, 55535554. doi:10.1073/pnas.1203263109

Kirby, K.R., Laurance, W.F., Albernaz, A.K., Schroth, G., Fearnside, P.M., Bergen, S., Venticinque, E.M., da Costa, C., 2006. The future of deforestation in the Brazilian Amazon. Futures 38, 432453. doi:10.1016/j.futures.2005.07.011

Kitzes, J., Harte, J., 2015. Predicting extinction debt from community patterns. Ecology 96(8), 21272136. doi:10.1890/14-1594.1

Kuussaari, M., Bommarco, R., Heikkinen, R.K., Helm, A., Krauss, J., Lindborg, R., Öckinger, E., Pärtel, M., Pino, J., Rodà, F., Stefanescu, C., Teder, T., Zobel, M., Steffan-Dewenter, I., 2009. Extinction debt: a challenge for biodiversity conservation. Trends Ecol. Evol. 24, 564-571. doi:10.1016/j.tree.2009.04.011

Lambert, T.D., Adler, G.H., Riveros, C.M., Lopez, L., Ascanio, R., Terborgh, J., 2003. Rodents on tropical land-bridge islands. J. Zool. 260, 179-187. doi:10.1017/S0952836903003637

Laurance, S.G.W., Stouffer, P.C., Laurance, W.F., 2004. Effects of road clearings on movement patterns of understory rainforest birds in central Amazonia. Conserv. Biol. 18, 1099-1109. doi:10.1111/j.1523-1739.2004.00268.x

Laurance, W., 2008. Theory meets reality: How habitat fragmentation research has transcended island biogeographic theory. Biol. Conserv. 141, 1731-1744. doi:10.1016/j.biocon.2008.05.011 
Lees, A.C., Peres, C.A., Fearnside, P.M., Schneider, M., Zuanon, J.A.S., 2016. Hydropower and the future of Amazonian biodiversity. Biodivers. Conserv. 25(3), 451-466. doi:10.1007/s10531-0161072-3

Leigh, E.G., Wright, S.J., Herre, E.A., Putz, F.E., 1993. The decline of tree diversity on newly isolated tropical islands: a test of a null hypothesis and some implications. Evol. Ecol. 7, 76-99. doi:10.1007/BF01237735

Lomolino, M. V., 2000. A call for a new paradigm of island biogeography. Glob. Ecol. Biogeogr. 9, 1-6. doi:10.1046/j.1365-2699.2000.00185.x

Lopez, L., Terborgh, J., 2007. Seed predation and seedling herbivory as factors in tree recruitment failure on predator-free forested islands. J. Trop. Ecol. 23, 129. doi:10.1017/S0266467406003828

MacArthur, R.H., Wilson, E.O., 1963. An equilibrium theory of insular zoogeography. Evolution 17, 373-387. doi:10.2307/2407089

MacArthur, R.H., Wilson, E.O., 1967. The theory of island biogeography. Princeton University Press, Princeton

Mendenhall, C.D., Karp, D.S., Meyer, C.F.J., Hadly, E. A, Daily, G.C., 2014. Predicting biodiversity change and averting collapse in agricultural landscapes. Nature 509, 213-7. doi:10.1038/nature13139

Mendenhall, C.D., Sekercioglu, C.H., Oviedo Brenes, F., Ehrlich, P.R., Daily, G.C., 2011. Predictive model for sustaining biodiversity in tropical countryside. Proc. Natl. Acad. Sci. U. S. A. 108, 16313-6. doi:10.1073/pnas.1111687108

Moore, R.P., Robinson, W.D., Lovette, I.J., Robinson, T.R., 2008. Experimental evidence for extreme dispersal limitation in tropical forest birds. Ecol Lett 11, 960-968. doi:10.1111/j.14610248.2008.01196.x

Murcia, C., 1995. Edge effects in fragmented forests: implications for conservation. Trends Ecol. Evol. 10, 58-62. doi:10.1016/S0169-5347(00)88977-6

Nilsson, C., Reidy, C. A., Dynesius, M., Revenga, C., 2005. Fragmentation and flow regulation of the world's large river systems. Science 308, 405-8. doi:10.1126/science.1107887

Oki, T., Kanae, S., 2006. Global Hydrological Cycles and World Water Resources. Science 313, 1068-1072. doi:10.1126/science.1128845

Palmeirim, A.F., Peres, C. A., Rosas, F.C.W., 2014. Giant otter population responses to habitat expansion and degradation induced by a mega hydroelectric dam. Biol. Conserv. 174, 30-38. doi:10.1016/j.biocon.2014.03.015

Peres, C. A., 2001. Synergistic Effects of Subsistence Hunting and Habitat Fragmentation on Amazonian Forest Vertebrates. Conserv. Biol. 15, 1490-1505. doi:10.1046/j.15231739.2001.01089.x

Peres, C. A., Lake, I.R., 2003. Extent of Nontimber Resource Extraction in Tropical Forests: Accessibility to Game Vertebrates by Hunters in the Amazon Basin. Conserv. Biol. 17, 521535. doi:10.1046/j.1523-1739.2003.01413.x 
Pinheiro, J.C., Bates, D.M., 2000. Mixed-effects Models in S and S-Plus. Springer, New York. doi: $10.1007 / \mathrm{b} 98882$

R Core Team, 2015. R: A Language and Environment for Statistical Computing. URL: https://www.rproject.org/ [Accessed 21/12/15]

Robinson, W.D., 1999. Long-Term Changes in the Avifauna of Barro Colorado Island, Panama, a Tropical Forest Isolate. Conserv. Biol. 13, 85-97. doi:10.1046/j.1523-1739.1999.97492.x

Sá-Oliveira, J.C., Hawes, J.E., Isaac-Nahum, V.J., Peres, C. A., 2015. Upstream and downstream responses of fish assemblages to an eastern Amazonian hydroelectric dam. Freshw. Biol. 60, 2037-2050. doi:10.1111/fwb.12628

Seabloom, E.W., Dobson, A.P., Stoms, D.M., 2002. Extinction rates under nonrandom patterns of habitat loss. Proc. Natl. Acad. Sci. 99, 11229-11234. doi:10.1073/pnas.162064899

Terborgh, J., Lopez, L., Nuñez, P., Rao, M., Shahabuddin, G., Orihuela, G., Riveros, M., Ascanio, R., Adler, G.H., Lambert, T.D., Balbas, L., 2001. Ecological meltdown in predator-free forest fragments. Science 294, 1923-6. doi:10.1126/science.1064397

Terborgh, J., Lopez, L., Tello, J., Yu, D., Bruni, A.R., 1997. Transitory states in Relaxing Ecosystems of Land Bridge Islands, in: Laurance, W.F., Bierregaard, R.O. (Eds.), Tropical Forest Remnants: Ecology, Management, and Conservation of Fragmented Communities. University of Chicago Press, London, pp. 256-274

Tilman, D., May, R.M., Lehman, C.L., Nowak, M.A., 1994. Habitat destruction and the extinction debt. Nature 371, 65-66. doi:10.1038/371065a0

Triantis, K.A., Guilhaumon, F., Whittaker, R.J., 2012. The island species-area relationship: biology and statistics. J. Biogeogr. 39, 215-231. doi:10.1111/j.1365-2699.2011.02652.x

Trussart, S., Messier, D., Roquet, V., Aki, S., 2002. Hydropower projects: A review of most effective mitigation measures. Energy Policy 30, 1251-1259. doi:10.1016/S0301-4215(02)00087-3

Turner, I.M., 1996. Species loss in fragments of tropical rain forest: a review of the evidence. J. Appl. Ecol. 33(2), 200-209. doi:10.2307/2404743

Wang, Y., Zhang, J., Feeley, K.J., Jiang, P., Ding, P., 2009. Life-history traits associated with fragmentation vulnerability of lizards in the Thousand Island Lake, China. Anim. Conserv. 12, 329-337. doi:10.1111/j.1469-1795.2009.00257.x

Watson, D.M., 2002. A conceptual framework for studying species composition in fragments, islands and other patchy ecosystems. J. Biogeogr. 29, 823-834. doi:10.1046/j.1365-2699.2002.00726.x

WCD, 2000. Dams and Development: A new framework for decision-making. World Commission on Dams. Earthscan Publications Ltd, London and Sterling, VA

Wearn, O.R., Reuman, D.C., Ewers, R.M., 2012. Extinction Debt and Windowns of Conservation Opportunity in the Brazilian Amazon. Science 337, 228-232. doi:10.1126/science.1219013

With, K. A., King, A.W., 2001. Analysis of landscape sources and sinks: The effect of spatial pattern on avian demography. Biol. Conserv. 100, 75-88. doi:10.1016/S0006-3207(00)00209-3 
Yu, M., Hu, G., Feeley, K.J., Wu, J., Ding, P., 2012. Richness and composition of plants and birds on land-bridge islands: effects of island attributes and differential responses of species groups. J. Biogeogr. 39, 1124-1133. doi:10.1111/j.1365-2699.2011.02676.x

653 


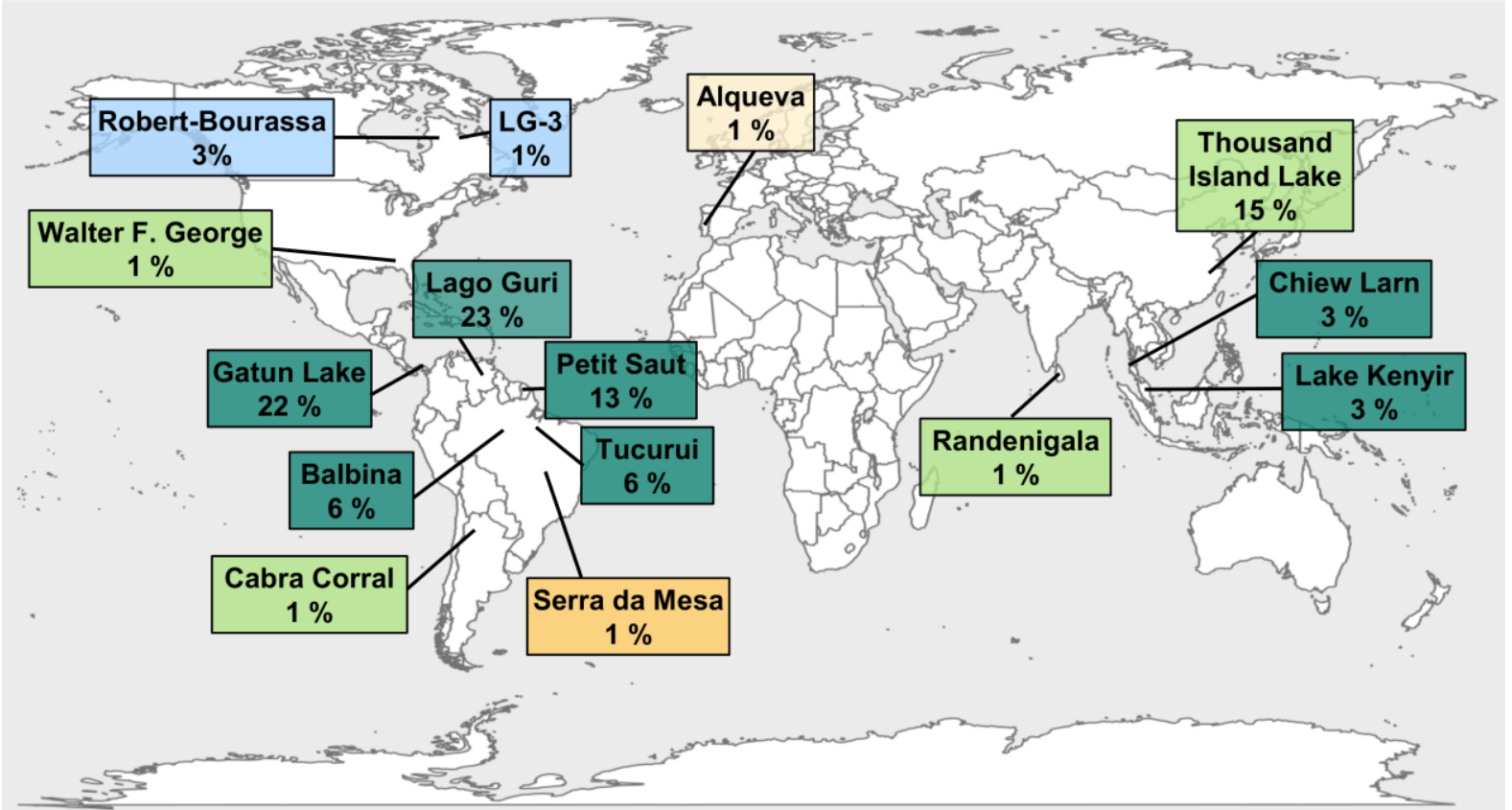

656 Figure 1: Geography of research detailing responses of terrestrial taxa to isolation on reservoir land-bridge islands. Dam names and the percentage of total dataset studies $(n=100)$ originating from each are presented. Broad habitat type is indicated by colour: dark green = wet tropical forest; light green $=$ subtropical forest; yellow $=$ tropical grassland (e.g. cerrado); cream $=$ Mediterranean forest; blue $=$ boreal forest . 
a

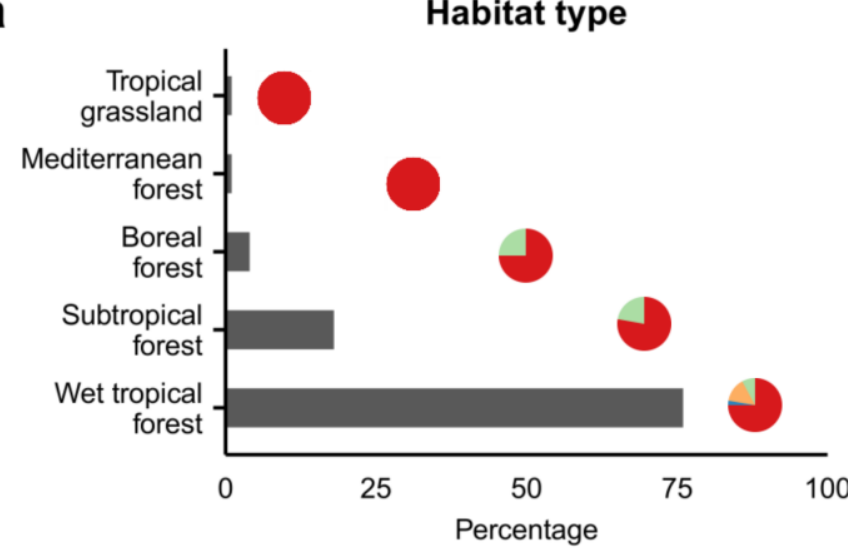

b

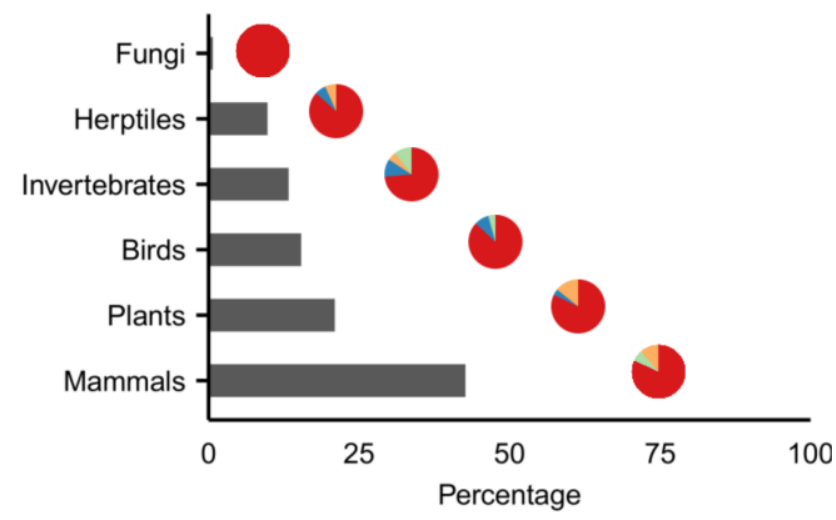

C

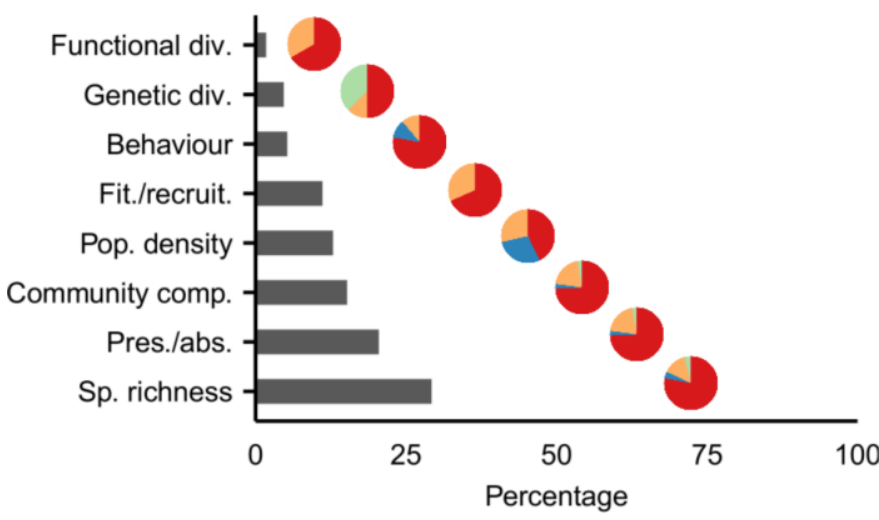

d

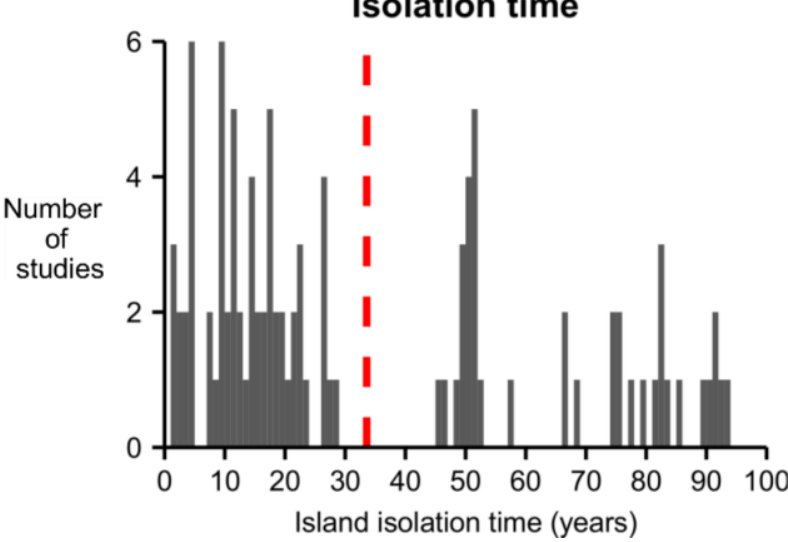


664 Figure 2: Overview of research presented within dataset studies $(n=100)$. 2a-c) present the 665 proportion of total studies (black bars) for habitat type, ecological metric and taxonomic 666 group investigated respectively; pie charts represent overall response directions (red = 667 negative; blue $=$ positive; green $=$ neutral; yellow $=$ variable). $2 \mathrm{~d}$ ) presents the distribution of 668 studies through island isolation time (red dashed line represents mean island isolation time, $669 \sim 33$ years).

670 [Single column fitting] 

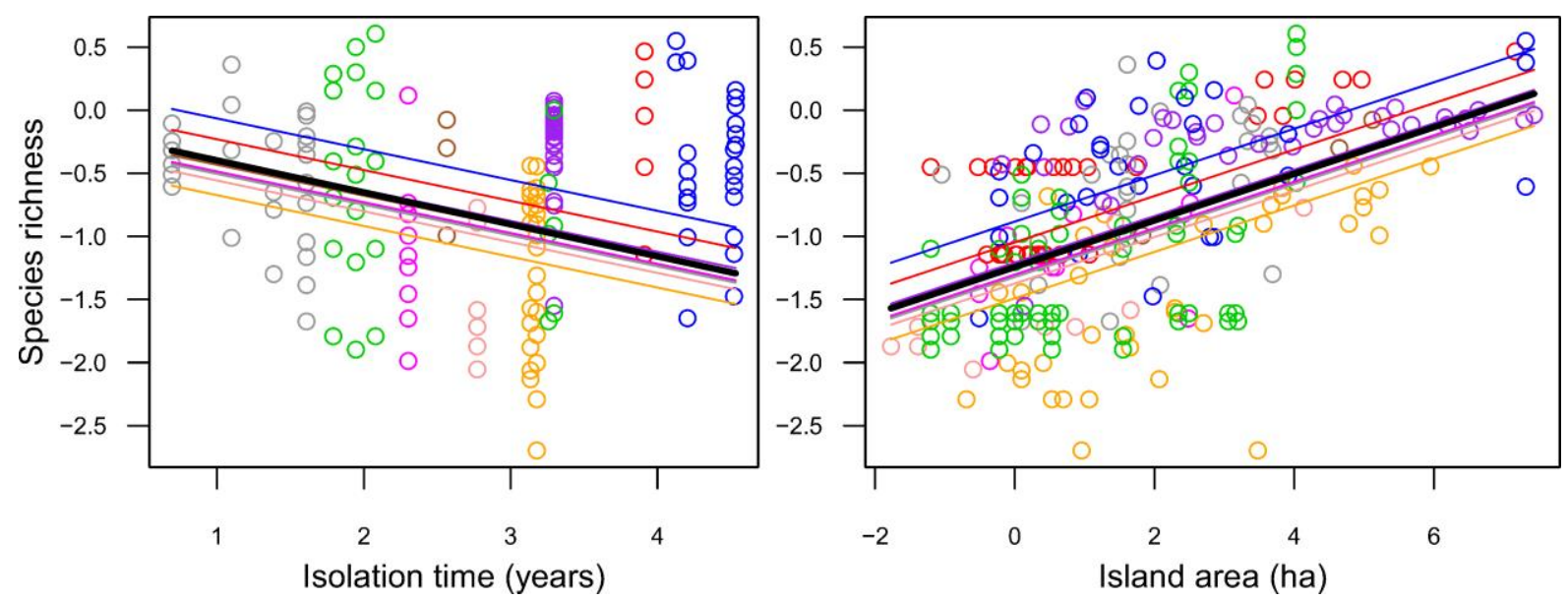

672 Figure 3: Analysis of species richness $\left(S_{\mathrm{RICH}}\right)$ data from 249 islands and 84 control sites available 673 from nine dams in three broad habitat types (wet tropical forest, subtropical forest, and tropical 674 grassland), modelled with time since island isolation ( $\left.T_{\text {ISO }}\right)$ and island area (AREA). Bold black lines 675 represent the slope for the overall model, with individual lines for each dam fitted using the BLUPs 676 extracted from random effects. Colour indicates dam identity: grey = Petit Saut; green = Chiew Larn; 677 magenta $=$ Lago Guri; brown $=$ Randenigala; light pink $=$ Cabra Corral; orange $=$ Lake Kenyir; purple $678=$ Balbina; red $=$ Thousand Island Lake; blue $=$ Gatun Lake. Axes are on a natural log scale.

\section{$679 \quad[2$ column fitting]}


680 Table 1: Coefficient estimates for fixed effects in the most parsimonious model used for 681 species richness analysis, with TAXA, DAM and STUDY as random effects; t-values >2 were 682 treated as significant.

\begin{tabular}{lccl}
\hline & Estimate & Standard Error & $\mathrm{t}$-val683 \\
\hline Intercept & -0.514 & 0.237 & -2.1684 \\
AREA & 0.185 & 0.015 & 11.944 \\
$T_{\text {ISO }}$ & -0.244 & 0.067 & -3.6985 \\
\hline
\end{tabular}

686

687 [Single column fitting] 


\section{APPENDIX A1}

\section{Full reference list for Appendix A}

Adler, G.H., 1994. Tropical forest fragmentation and isolation promote asynchrony among populations of a frugivorous rodent. J. Anim. Ecol. 63, 903-911

Adler, G.H., Beatty, R.P.,1997. Changing reproductive rates in a Neotropical forest rodent, Proechimys semispinosus. J. Anim. Ecol. 66, 472-480

Adler, G.H., Seamon, J.O., 1991. Distribution and abundance of a tropical rodent, the spiny rat, on islands in Panama. J. Trop. Ecol. 7, 349-360. doi:10.1017/S0266467400005617

Aponte, C., Barreto, G.R., Terborgh, J., 2003. Consequences of Habitat Fragmentation on Age Structure and Life History in a Tortoise Population. Biotropica 35, 550-555

Arnold, A.E., Asquith, N.M., 2002. Herbivory in a fragmented tropical forest: patterns from islands at Lago Gatun, Panama. Biodivers. Conserv. 11, 1663-1680

Asquith, N.M., Mejía-Chang, M., 2005. Mammals, Edge Effects , and the Loss of Tropical Forest Diversity. Ecology 86, 379-390

Asquith, N.M., Terborgh, J., Arnold, A.E., Riveros, C.M., 1999. The fruits the agouti ate: Hymenaea courbaril seed fate when its disperser is absent. J. Trop. Ecol. 15, 229-235

Asquith, N.M., Wright, S.J., Clauss, M.J., 1997. Does mammal community composition control recruitment in neotropical forests? Evidence from Panama. Ecology 78, 941-946

Badano, E.I., Regidor, H.A., Nunez, H.A., Acosta, R., Gianoli, E., 2005. Species richness and structure of ant communities in a dynamic archipelago: effects of island area and age. $\mathrm{J}$. Biogeogr. 32, 221-227

Bastos, H.B., Gonçalves, E.C., Ferrari, S.F., Silva, A., Schneider, M.P.C., 2010. Genetic structure of red-handed howler monkey populations in the fragmented landscape of Eastern Brazilian Amazonia. Genet. Mol. Biol. 33, 774-80

Bégin, Y., Sirois, L., Meunier, C., 2010. The effects of hydroelectric flooding on a reservoir's peripheral forests and newly created forest islands, in: Stoffel, M., Bollschweiler, M., Butler, D.R., Luckman, B.H. (Eds.), Tree Rings and Natural Hazards: A State-of-theArt, Advances in Global Change Research. Springer Netherlands, Dordrecht, pp. 241256. doi:10.1007/978-90-481-8736-2

Benchimol, M., Peres, C.A, 2015a. Edge-mediated compositional and functional decay of tree assemblages in Amazonian forest islands after 26 years of isolation. J. Ecol. 103, 408-420. doi:10.1111/1365-2745.12371

Benchimol, M., Peres, C.A, 2015b. Predicting local extinctions of Amazonian vertebrates in forest islands created by a mega dam. Biol. Conserv. 187, 61-72. doi:10.1016/j.biocon.2015.04.005 
Benchimol, M., Peres, C.A., 2015c. Widespread Forest Vertebrate Extinctions Induced by a Mega Hydroelectric Dam in Lowland Amazonia. PLoS One 1-15. doi:10.5061/dryad.c301h

Benchimol, M., Venticinque, E.M., 2014. Responses of Primates to Landscape Change in Amazonian Land-bridge islands-a Multi-scale Analysis. Biotropica 0, 1-9. doi:10.1111/btp.12122

Benchimol, M., Venticinque, E.M., 2010. Harpy Eagle (Harpia harpyja) predation on an Infant brown Capuchin Monkey (Cebus apella) in the Brazilian Amazon. Rev. Bras. Ornitol. 18, 352-354

Boyett, W.D., Endries, M.J., Adler, G.H., 2000. Colonization-extinction dynamics of oppossums on small islands in Panama. Can. J. Zool. 78, 1972-1979

Brandão, R., Araújo, A., 2008. Changes in Anuran Species Richness and Abundance Resulting from Hydroelectric Dam Flooding in Central Brazil. Biotropica 40, 263-266

Carvalho, L.S., Gomes, J.O., Neckel-Oliveira, S., Lo-Man-Hung, N.F., 2012. Microhabitat use and intraspecific associations in the whip spider Heterophrynus longicornis (Arachnida: Amblypygi ) in forest fragments formed by the Tucuruí Dam lake , Pará , Brazil 46, 1263-1272

Cosson, J., Pons, J.M., Masson, D., 1999. Effects of forest fragmentation on frugivorous and nectarivorous bats in French Guiana. J. Trop. Ecol. 15, 515-534

Cosson, J.F., Ringuet, S., Claessens, O., de Massary, J.C., Dalecky, A., Villiers, J.F., Granjon, L., Pons, J.M., 1999. Ecological changes in recent land-bridge islands in French Guiana, with emphasis on vertebrate communities. Biol. Conserv. 91, 213-222. doi:10.1016/S0006-3207(99)00091-9

Crete, M., Huot, J., Fortin, M.-J., Doucet, G., 1997. Comparison of plant and animal diversity on new reservoir islands and established lake islands in Northern Boreal Forest of Quebec. Can. field-naturalist 111, 407-416

Daleky, A., Chauvet, S., Ringuet, S., Claessens, O., Juda, J., Larue, M., Cosson, J.F., 2002. Large mammals on small islands: short-term effects of forest fragmentation on the large mammal fauna in French Guiana. Rev. d'ecologie 57, 145-164

Davies, R., 2002. Feeding group responses of a Neotropical termite assemblage to rain forest fragmentation. Oecologia 133, 233-242. doi:10.1007/s00442-002-1011-8

Davies, R.G., Hernández, L.M., Eggleton, P., Didham, R.K., Fagan, L.L., Winchester, N.N., 2003. Environmental and spatial influences upon species composition of a termite assemblage across neotropical forest islands. J. Trop. Ecol. 19, 509-524. doi:10.1017/S0266467403003560

Ding, Z., Feeley, K.J., Wang, Y., Pakeman, R.J., Ding, P., 2013. Patterns of bird functional diversity on land-bridge island fragments. J. Anim. Ecol. 781-790. doi:10.1111/13652656.12046 
Emer, C., Venticinque, E.M., Fonseca, C.R., 2013. Effects of dam-induced landscape fragmentation on amazonian ant-plant mutualistic networks. Conserv. Biol. 27, 763-73. doi:10.1111/cobi.12045

Ennen, J.R., Birkhead, R.D., Kreiser, B.R., Gaillard, D.L., Qualls, C.P., Lovich, J.E., 2011. The effects of isolation on the demography and genetic diversity of long-lived species: implications for conservation and management of the gopher tortoise (Gopherus polyphemus). Herpetol. Conserv. Biol. 6, 202-214.

Estrada-Villegas, S., Meyer, C.F.J., Kalko, E.K.V., 2010. Effects of tropical forest fragmentation on aerial insectivorous bats in a land-bridge island system. Biol. Conserv. 143, 597-608. doi:10.1016/j.biocon.2009.11.009

Feeley, K., 2003. Analysis of avian communities in Lake Guri, Venezuela, using multiple assembly rule models. Oecologia 137, 104-13. doi:10.1007/s00442-003-1321-5

Feeley, K.J., Gillespie, T.W., Lebbin, D.J., Walter, H.S., 2007. Species characteristics associated with extinction vulnerability and nestedness rankings of birds in tropical forest fragments. Anim. Conserv. 10, 493-501. doi:10.1111/j.1469-1795.2007.00140.x

Feeley, K.J., Terborgh, J.W., 2008. Direct versus indirect effects of habitat reduction on the loss of avian species from tropical forest fragments. Anim. Conserv. 11, 353-360. doi:10.1111/j.1469-1795.2008.00182.x

Feeley, K.J., Terborgh, J.W., 2006. Habitat Fragmentation and Effects of Herbivore (Howler Monkey) Abundances on Bird Species Richness. Ecology 87, 144-150

Feeley, K.J., Terborgh, J.W., 2005. The Effects of Herbivore Density on Soil Nutrients and Tree Growth in Tropical Forest Fragments. Ecology 86, 116-124

Feer, F., Hingrat, Y., 2005. Effects of Forest Fragmentation on a Dung Beetle Community in French Guiana. Conserv. Biol. 19, 1103-1112. doi:10.1111/j.1523-1739.2005.00087.x

Ferreira, L. V, Neckel-Oliveira, S., Galatti, U., Fáveri, S.B., Parolin, P., 2012. Forest structure of artificial islands in the Tucuruí dam reservoir in northern Brazil: a test corearea model. Acta Amaz. 42, 221-226.

Gibson, L., Lynam, A.J., Bradshaw, C.J. A, He, F., Bickford, D.P., Woodruff, D.S., Bumrungsri, S., Laurance, W.F., 2013. Near-complete extinction of native small mammal fauna 25 years after forest fragmentation. Science 341, 1508-10. doi:10.1126/science. 1240495

Granjon, L., Cosson, J., Judas, J., Ringlet, S., 1996. Influence of tropical rainforest fragmentation on mammal communities in French Guiana: short-term effects. Acta Oecologica 17, 673-672

Granjon, L., Ringuet, S., Cheylan, G., 2002. Evolution of small terrestrial mammal species richness on newly formed islands in primary tropical forest of French Guiana: a 6 year study. Rev. d'ecologie 8, 131-144. 
Henry, M., Cosson, J.F., Pons, J.M., 2010. Modelling multi-scale spatial variation in species richness from abundance data in a complex neotropical bat assemblage. Ecol. Modell. 221, 2018-2027. doi:10.1016/j.ecolmodel.2010.05.011

Henry, M., Cosson, J.-F., Pons, J.-M., 2007a. Abundance may be a misleading indicator of fragmentation-sensitivity: The case of fig-eating bats. Biol. Conserv. 139, 462-467. doi:10.1016/j.biocon.2007.06.024

Henry, M., Pons, J.-M., Cosson, J.-F., 2007b. Foraging behaviour of a frugivorous bat helps bridge landscape connectivity and ecological processes in a fragmented rainforest. J. Anim. Ecol. 76, 801-13. doi:10.1111/j.1365-2656.2007.01258.x

Hu, G., Feeley, K.J., Wu, J., Xu, G., Yu, M., 2011. Determinants of plant species richness and patterns of nestedness in fragmented landscapes: evidence from land-bridge islands. Landsc. Ecol. 26, 1405-1417. doi:10.1007/s10980-011-9662-7

Hu, G., Wu, J., Feeley, K.J., Xu, G., Yu, M., 2012. The effects of landscape variables on the species-area relationship during late-stage habitat fragmentation. PLoS One 7, e43894. doi:10.1371/journal.pone.0043894

Karr, J.R., 1990. Avian Survival Rates and the Extinction Process on Barro Colorado Island, Panama Island. Conserv. Biol. 4, 391-397

Karr, J.R., 1982a. Population Variability and Extinction in the Avifauna of a Tropical Land Bridge Island. Ecology 63, 1975-1978

Karr, J.R., 1982b. Avian Extinction on Barro Colorado Island, Panama: A Reassessment. Am. Nat. 119, 220-239

Lambert, T.D., Adler, G.H., Riveros, C.M., Lopez, L., Ascanio, R., Terborgh, J., 2003. Rodents on tropical land-bridge islands. J. Zool. 260, 179-187. doi: $10.1017 /$ S0952836903003637

Larsen, T.H., Lopera, A., Forsyth, A., 2008. Understanding trait-dependent community disassembly: dung beetles, density functions, and forest fragmentation. Conserv. Biol. 22, 1288-98. doi:10.1111/j.1523-1739.2008.00969.x

Larsen, T.H., Williams, N.M., Kremen, C., 2005. Extinction order and altered community structure rapidly disrupt ecosystem functioning. Ecol. Lett. 8, 538-47. doi:10.1111/j.1461-0248.2005.00749.x

Leigh, E.G., Wright, S.J., Herre, E.A., Putz, F.E., 1993. The decline of tree diversity on newly isolated tropical islands: a test of a null hypothesis and some implications. Evol. Ecol. 7, 76-99.

Lima, J., Galatti, U., Lima, C., Faveri, S., Vasconcelos, H., Neckel-Oliveira, S., 2015. Amphibians on Amazonian Land-Bridge Islands are Affected More by Area Than Isolation. Biotropica 47, 369-376 
Lopez, G.O., Terborgh, J., Ceballos, N., 2005. Food selection by a hyperdense population of red howler monkeys (Alouatta seniculus). J. Trop. Ecol. 21, 445-450. doi: $10.1017 / \mathrm{S} 0266467405002415$

Lopez, L., Terborgh, J., 2007. Seed predation and seedling herbivory as factors in tree recruitment failure on predator-free forested islands. J. Trop. Ecol. 23, 129. doi:10.1017/S0266467406003828

Lu, J., Jiang, L., Yu, L., Sun, Q., 2011. Local factors determine plant community structure on closely neighbored islands. PLoS One 6, e19762. doi:10.1371/journal.pone.0019762

Lynam, A.J., 1997. Rapid decline of small mammal diversity in Monsoon evergreen fragments in Thailand, in: Tropical Forest Remnants: Ecology, Management, and Conservation of Fragmented Communities. pp. 222-240

Lynam, A.J., Billick, I., 1999. Differential responses of small mammals to fragmentation in a Thailand tropical forest. Biol. Conserv. 91, 191-200

Mangan, S.A., Eom, A.-H., Adler, G.H., Yavitt, J.B., Herre, E.A., 2004. Diversity of arbuscular mycorrhizal fungi across a fragmented forest in Panama: insular spore communities differ from mainland communities. Oecologia 141, 687-700. doi:10.1007/s00442-004-1684-2

Meyer, C.F.J., Kalko, E.K. V., 2008a. Assemblage-level responses of phyllostomid bats to tropical forest fragmentation: land-bridge islands as a model system. J. Biogeogr. 35, 1711-1726. doi:10.1111/j.1365-2699.2008.01916.x

Meyer, C.F.J., Kalko, E.K. V., 2008b. Bat assemblages on Neotropical land-bridge islands: nested subsets and null model analyses of species co-occurrence patterns. Divers. Distrib. 14, 644-654. doi:10.1111/j.1472-4642.2007.00462.x

Meyer, C.F.J., Kalko, E.K. V., Kerth, G., 2009. Small-Scale Fragmentation Effects on Local Genetic Diversity in Two Phyllostomid Bats with Different Dispersal Abilities in Panama. Biotropica 41, 95-102. doi:10.1111/j.1744-7429.2008.00443.x

Milton, K., Lozier, J.D., Lacey, E. A., 2008. Genetic structure of an isolated population of mantled howler monkeys (Alouatta palliata) on Barro Colorado Island, Panama. Conserv. Genet. 10, 347-358. doi:10.1007/s10592-008-9584-3

Norconk, M.A., Grafton, B.W., 2003. Changes in forest composition and potential feeding tree availability on a small land-bridge island in Lago Guri, Venezuela, in: Marsh, L.K. (Ed.), Primates in Fragments. Springer US, pp. 211-227

Peetz, A., Norconk, M.A., Kinzey, W.G., 1992. Predation by jaguar on howler monkeys (Alouatta seniculus) in Venezuela. Am. J. Primatol. 28, 223-228

Pons, J.-M., Cosson, J.-F., 2002. Use of forest fragments by animalivorous bats in French Guiana. Rev. d'ecologie 57, 117-130 
Qie, L., Lee, T.M., Sodhi, N.S., Lim, S.L.-H., 2011. Dung beetle assemblages on tropical land-bridge islands: small island effect and vulnerable species. J. Biogeogr. 38, 792804. doi:10.1111/j.1365-2699.2010.02439.x

Rao, M., 2000. Variation in leaf-cutter ant (Atta sp.) densities in forest isolates: the potential role of predation. J. Trop. Ecol. 16, 209-225.

Rao, M., Terborgh, J., Nunez, P., 2001. Increased Plant Herbivory in Forest Isolates: Implications for Plant Community Structure and Composition. Conserv. Biol. 15, 624633.

Rebelo, H., Rainho, A., 2009. Bat conservation and large dams: spatial changes in habitat use caused by Europe's largest reservoir. Endanger. Species Res. 8, 61-68. doi:10.3354/esr00100

Ringuet, S., 2000. An assessment of the potential influence of rainforest fragmentation on small terrestrial mammal predation in French Guiana. Rev. d'ecologie 55, 101-116

Robinson, W.D., 1999. Long-Term Changes in the Avifauna of Barro Colorado Island, Panama, a Tropical Forest Isolate. Conserv. Biol. 13, 85-97. doi:10.1046/j.15231739.1999.97492.x

Shahabuddin, G., Herzner, G.A., Aponte, C., Gomez, M. del C., 2000. Persistence of a frugivorous butterfly species in Venezuelan forest fragments: the role of movement and habitat quality. Biodivers. Conserv. 9, 1623-1641

Shahabuddin, G., Ponte, C. A., 2005. Frugivorous butterfly species in tropical forest fragments: correlates of vulnerability to extinction. Biodivers. Conserv. 14, 1137-1152. doi:10.1007/s10531-004-7842-3

Shahabuddin, G., Terborgh, J.W., 2000. Frugivorous butterflies in Venezuelan forest fragments: abundance, diversity and the effects of isolation. J. Trop. Ecol. 15, 703-722

Silva, S.S.B., Ferrari, S.F., 2009. Behavior patterns of southern bearded sakis (Chiropotes satanas) in the fragmented landscape of eastern Brazilian Amazonia. Am. J. Primatol. 71, 1-7. doi:10.1002/ajp.20624

Terborgh, J., Feeley, K., Silman, M., Nunez, P., Balukjian, B., 2006. Vegetation dynamics of predator-free land-bridge islands. J. Ecol. 94, 253-263. doi:10.1111/j.13652745.2006.01106.x

Terborgh, J., Lopez, L., Nuñez, P., Rao, M., Shahabuddin, G., Orihuela, G., Riveros, M., Ascanio, R., Adler, G.H., Lambert, T.D., Balbas, L., 2001. Ecological meltdown in predator-free forest fragments. Science 294, 1923-6. doi:10.1126/science.1064397

Terborgh, J., Lopez, L., Tello, J.S., 1997a. Bird Communities in Transition: The Lago Guri Islands. Ecology 78, 1494-1501

Terborgh, J., Lopez, L., Tello, J.S., Yu, D., Bruni, A.R., 1997b. Transitory states in Relaxing Ecosystems of Land Bridge Islands, in: Laurance, W.F., Bierregaard, R.O. (Eds.), 

Tropical Forest Remnants: Ecology, Management, and Conservation of Fragmented Communities. University of Chicago Press, London, pp. 256-274

Tremblay, A., Begin, Y., 2005. The effects of snow packing on tree growth forms on an island in a recently created reservoir in northern Quebec. Ecoscience 12, 530-539

Tremblay, A., Begin, Y., 2000. The response of black spruce to the climatic influence of Robert-Bourassa Reservoir, in northern Quebec. Ecoscience 7, 228-236

Veiga, L.M., Ferrari, S.F., 2006. Predation of Arthropods by Southern Bearded Sakis (Chiropotes satanas) in Eastern Brazilian Amazonia. Am. J. Primatol. 68, 209-215. doi:10.1002/ajp

Wang, Y., Zhang, J., Feeley, K.J., Jiang, P., Ding, P., 2009. Life-history traits associated with fragmentation vulnerability of lizards in the Thousand Island Lake, China. Anim. Conserv. 12, 329-337. doi:10.1111/j.1469-1795.2009.00257.x

Wang, Y., Bao, Y., Yu, M., Xu, G., Ding, P., 2010. Nestedness for different reasons: the distributions of birds, lizards and small mammals on islands of an inundated lake. Divers. Distrib. 16, 862-873. doi:10.1111/j.1472-4642.2010.00682.x

Wang, Y., Chen, S., Ding, P., 2011. Testing multiple assembly rule models in avian communities on islands of an inundated lake, Zhejiang Province, China. J. Biogeogr. 38, 1330-1344. doi:10.1111/j.1365-2699.2011.02502.x

Wang, Y., Zhang, M., Wang, S., Ding, Z., Zhang, J., Sun, J., Li, P., Ding, P., 2012a. No evidence for the small-island effect in avian communities on islands of an inundated lake. Oikos 121, 1945-1952. doi:10.1111/j.1600-0706.2012.20322.x

Wang, Y., Wang, X., Ding, P., 2012b. Nestedness of snake assemblages on islands of an inundated lake. Curr. Zool. 58, 828-836

Wang, Y., Zhu, Y., Wang, Y., 2012c. Differences in spatial genetic structure and diversity in two mosses with different dispersal strategies in a fragmented landscape. J. Bryol. 34, 916. doi:10.1179/1743282011Y.0000000035

Wang, Y., Lane, A., Ding, P., 2012d. Sex-biased dispersal of a frog (Odorrana schmackeri) is affected by patch isolation and resource limitation in a fragmented landscape. PLoS One 7, e47683. doi:10.1371/journal.pone.0047683

Weerakoon, W.M.S.K., 2001. Comparative richness of amphibians inhabiting the islands at Randenigala reservoir with mainland of the Victoriya Randenigala Ranambe (VRR) sanctuary. Lyriocephalus 44, 124-129

Willis, E.O., 1974. Populations and Local Extinctions of Birds on Barro Colorado Island, Panama. Ecol. Monogr. 44, 153-169

Wright, S.J., Gompper, M.E., DeLeon, B., 1994. Are large predators keystone species in Neotropical forestsThe evidence from Barro Colorado Island. Oikos 71, 279-294 
Yong, D.L., Lohman, D.J., Gan, C.W., Qie, L., Lim, S.L.-H., 2012. Tropical butterfly communities on land-bridge islands in Peninsular Malaysia. Raffles Bull. Zool. 25, 161172

Yong, D.L., Qie, L., Sodhi, N.S., Koh, L.P., Peh, K.S.-H., Lee, T.M., Lim, H.C., Lim, S.L.H., 2010. Do insectivorous bird communities decline on land-bridge forest islands in Peninsular Malaysia? J. Trop. Ecol. 27, 1-14. doi:10.1017/S0266467410000520

Yu, L., Lu, J., 2011. Does landscape fragmentation influence sex ratio of dioecious plants? A case study of Pistacia chinensis in the Thousand-Island Lake region of China. PLoS One 6, e22903. doi:10.1371/journal.pone.0022903

Yu, M., Hu, G., Feeley, K.J., Wu, J., Ding, P., 2012. Richness and composition of plants and birds on land-bridge islands: effects of island attributes and differential responses of species groups. J. Biogeogr. 39, 1124-1133. doi:10.1111/j.1365-2699.2011.02676.x

Yuan, N., Comes, H.P., Mao, Y.-R., Qi, X.-S., Qiu, Y.-X., 2012. Genetic effects of recent habitat fragmentation in the Thousand-Island Lake region of southeast China on the distylous herb Hedyotis chrysotricha (Rubiaceae). Am. J. Bot. 99, 1715-25. doi:10.3732/ajb.1200054

Zhang, X., Xu, G., Shen, D., Gu, Y., Gao, H., Luo, X., Chen, X., 2007. Maintenance and natural regeneration of Castanopsis sclerophylla populations on islands of Qiandao Lake Region, China. Acta Ecol. Sin. 27, 424-430. doi:10.1016/S1872-2032(07)60014-6 
965 Summary of research articles used in the species richness analysis. For full references, see

966 Appendix A1. For data used in the analysis, see Appendix B.

\begin{tabular}{|c|c|c|c|c|c|c|c|c|}
\hline Reference & Habitat type & Region & Country & Dam & $\begin{array}{l}\text { Isolation } \\
\text { time } \\
\text { (years) }\end{array}$ & $\begin{array}{l}\text { Number } \\
\text { of } \\
\text { islands } \\
\text { studied }\end{array}$ & $\begin{array}{l}\text { Number of } \\
\text { control } \\
\text { sites }\end{array}$ & $\begin{array}{l}\text { Island } \\
\text { areas } \\
\text { (ha) }\end{array}$ \\
\hline $\begin{array}{l}\text { Badano et al. } \\
(2005)\end{array}$ & $\begin{array}{l}\text { Subtropical } \\
\text { forest }\end{array}$ & $\begin{array}{l}\text { South } \\
\text { America }\end{array}$ & Argentina & $\begin{array}{l}\text { Cabra } \\
\text { Corral }\end{array}$ & 15 & 9 & 1 & $\begin{array}{l}0.16- \\
62.5 \\
\end{array}$ \\
\hline $\begin{array}{l}\text { Benchimol \& } \\
\text { Peres (2015) }\end{array}$ & $\begin{array}{l}\text { Wet tropical } \\
\text { forest }\end{array}$ & $\begin{array}{l}\text { South } \\
\text { America }\end{array}$ & Brazil & Balbina & 26 & 34 & 12 & $<1-1690$ \\
\hline $\begin{array}{l}\text { Cosson et al. } \\
(1999) \mathrm{b}\end{array}$ & $\begin{array}{l}\text { Wet tropical } \\
\text { forest }\end{array}$ & $\begin{array}{l}\text { South } \\
\text { America }\end{array}$ & $\begin{array}{l}\text { French } \\
\text { Guiana }\end{array}$ & Petit Saut & 1 & 6 & 3 & $2-40$ \\
\hline $\begin{array}{l}\text { Estrada- } \\
\text { Villegas et al. } \\
(2010) \\
\end{array}$ & $\begin{array}{l}\text { Wet tropical } \\
\text { forest }\end{array}$ & $\begin{array}{l}\text { Central } \\
\text { America }\end{array}$ & Panama & $\begin{array}{l}\text { Gatun } \\
\text { Lake }\end{array}$ & 92 & 8 & 6 & $2.5-50$ \\
\hline $\begin{array}{l}\text { Feer \& } \\
\text { Hingrat (2005) }\end{array}$ & $\begin{array}{l}\text { Wet tropical } \\
\text { forest }\end{array}$ & $\begin{array}{l}\text { South } \\
\text { America }\end{array}$ & $\begin{array}{l}\text { French } \\
\text { Guiana }\end{array}$ & Petit Saut & 4 & 7 & 3 & $1.1-25.5$ \\
\hline $\begin{array}{l}\text { Gibson et al. } \\
(2013)\end{array}$ & $\begin{array}{l}\text { Wet tropical } \\
\text { forest }\end{array}$ & Asia & Thailand & $\begin{array}{l}\text { Chiew } \\
\text { Larn } \\
\end{array}$ & 26 & 16 & 1 & $0.3-56.3$ \\
\hline $\begin{array}{l}\text { Granjon et al. } \\
(1996)\end{array}$ & $\begin{array}{l}\text { Wet tropical } \\
\text { forest }\end{array}$ & $\begin{array}{l}\text { South } \\
\text { America }\end{array}$ & $\begin{array}{l}\text { French } \\
\text { Guiana }\end{array}$ & Petit Saut & 1 & 10 & 1 & $0.35-30$ \\
\hline Karr (1982)b & $\begin{array}{l}\text { Wet tropical } \\
\text { forest }\end{array}$ & $\begin{array}{l}\text { Central } \\
\text { America }\end{array}$ & Panama & $\begin{array}{l}\text { Gatun } \\
\text { Lake }\end{array}$ & 66 & 1 & 2 & 1500 \\
\hline $\begin{array}{l}\text { Leigh et al. } \\
\text { (1993) }\end{array}$ & $\begin{array}{l}\text { Wet tropical } \\
\text { forest }\end{array}$ & $\begin{array}{l}\text { Central } \\
\text { America }\end{array}$ & Panama & $\begin{array}{l}\text { Gatun } \\
\text { Lake }\end{array}$ & 66 & 7 & 4 & $0.6-1500$ \\
\hline $\begin{array}{l}\text { Meyer \& } \\
\text { Kalko (2008)a }\end{array}$ & $\begin{array}{l}\text { Wet tropical } \\
\text { forest }\end{array}$ & $\begin{array}{l}\text { Central } \\
\text { America }\end{array}$ & Panama & $\begin{array}{l}\text { Gatun } \\
\text { Lake }\end{array}$ & 91 & 11 & 6 & $2.5-50$ \\
\hline $\begin{array}{l}\text { Pons \& } \\
\text { Cosson (2002) }\end{array}$ & $\begin{array}{l}\text { Wet tropical } \\
\text { forest }\end{array}$ & $\begin{array}{l}\text { South } \\
\text { America }\end{array}$ & $\begin{array}{l}\text { French } \\
\text { Guiana }\end{array}$ & Petit Saut & 2 & 16 & 1 & $<6-28$ \\
\hline $\begin{array}{l}\text { Qui et al. } \\
\text { (2011) }\end{array}$ & $\begin{array}{l}\text { Wet tropical } \\
\text { forest }\end{array}$ & Asia & Malaysia & \begin{tabular}{|l|} 
Lake \\
Kenyir \\
\end{tabular} & 23 & 24 & 3 & $<1-383.3$ \\
\hline $\begin{array}{l}\text { Terborgh et al. } \\
\text { (1997) }\end{array}$ & $\begin{array}{l}\text { Wet tropical } \\
\text { forest }\end{array}$ & $\begin{array}{l}\text { South } \\
\text { America }\end{array}$ & Venezuela & Lago Guri & 9 & 12 & 1 & $1-350$ \\
\hline $\begin{array}{l}\text { Wang et al. } \\
(2009)\end{array}$ & $\begin{array}{l}\text { Subtropical } \\
\text { forest }\end{array}$ & Asia & China & $\begin{array}{l}\text { Thousand } \\
\text { Island } \\
\text { Lake } \\
\end{array}$ & 49 & 42 & 7 & $\begin{array}{l}0.67- \\
1289.23\end{array}$ \\
\hline $\begin{array}{l}\text { Weerakoon } \\
(2009)\end{array}$ & $\begin{array}{l}\text { Subtropical } \\
\text { forest }\end{array}$ & Asia & Sri Lanka & $\begin{array}{l}\text { Randeniga } \\
\text { la }\end{array}$ & 12 & 6 & 5 & $2-167$ \\
\hline $\begin{array}{l}\text { Yong et al. } \\
(2010)\end{array}$ & $\begin{array}{l}\text { Wet tropical } \\
\text { forest }\end{array}$ & Asia & Malaysia & $\begin{array}{l}\text { Lake } \\
\text { Kenyir }\end{array}$ & 22 & 6 & 2 & $\begin{array}{l}<20- \\
>100\end{array}$ \\
\hline $\begin{array}{l}\text { Yong et al. } \\
(2012)\end{array}$ & $\begin{array}{l}\text { Wet tropical } \\
\text { forest }\end{array}$ & Asia & Malaysia & $\begin{array}{l}\text { Lake } \\
\text { Kenyir }\end{array}$ & 22 & 6 & 2 & $\begin{array}{l}<20- \\
>100\end{array}$ \\
\hline
\end{tabular}


970 Coefficients for the fixed effects of models that treat study identity, dam, and taxonomic 971 group as random effects. The Chi-square $\left(\mathrm{x}^{2}\right)$ value and $\mathrm{p}$-value from model comparison by 972 ANOVA is given. The final model used in analysis only included significant fixed effects: 973 AREA and $T_{\text {ISO }}$. Values presented in this table are from model comparisons using a reduced dataset (n 974 islands $=148$ ) to account for missing values. Following model comparison, the final model was used 975 on the full dataset ( $\mathrm{n}$ islands $=249$ ) which did not have missing values for the variables included in 976 the model.

\begin{tabular}{|c|c|c|c|c|c|c|}
\hline Fixed effects & Estimate & $\mathrm{SE}$ & $\mathrm{t}$-value & $\mathrm{df}$ & $\mathrm{x}^{2}$ & $\mathrm{p}$-value \\
\hline Intercept & -0.514 & 0.237 & -2.168 & & & \\
\hline AREA & 0.237 & 0.02 & 11.958 & 1 & 94.744 & $<0.001$ \\
\hline$T_{\text {ISO }}$ & -0.328 & 0.069 & -4.720 & 1 & 16.136 & $<0.001$ \\
\hline$D_{\text {MAIN }}$ & -0.037 & 0.039 & -0.951 & 1 & 0.894 & 0.344 \\
\hline$D_{\text {ISLAND }}$ & -0.062 & 0.043 & -1.434 & 1 & 1.991 & 0.158 \\
\hline
\end{tabular}

\section{Table B3}

979 Intercepts for the best unbiased linear predictors (BLUPs) for each dam generated using the 980 'ranef' function in lme4 (Bates et al., 2014). Negative BLUPs indicate lower species richness 981 values than predicted by the model; positive BLUPs indicate higher species richness values 982 than predicted.

\begin{tabular}{|l|l|}
\hline Dam & Intercept (Dam) \\
\hline Balbina & 0.0367 \\
\hline Cabra Corral & -0.131 \\
\hline Chiew Larn & -0.071 \\
\hline Gatun Lake & 0.361 \\
\hline Lago Guri & -0.059 \\
\hline Lake Kenyir & -0.247 \\
\hline Petit Saut & -0.079 \\
\hline Randenigala & -0.007 \\
\hline Thousand Island Lake & 0.196 \\
\hline
\end{tabular}

